\title{
A Constitution Made for Mandela, A Constitutional Jurisprudence Developed for Zuma
}

The Erosion of Discretion of the Executive in Foreign Relations

Dire Tladi

\section{AN INTRODUCTION}

The field of law that is the subject of this book, foreign relations law, is referred to in South Africa simply as constitutional law or, the intersection of constitutional law and international law. It does not concern the rules of international law as such but may well concern processes that may lead to the making of international law, whether practice for the purposes of customary international law and, more often, treaty-making conduct. Contestations over who participates in international activities on behalf of the state, and under what circumstances international engagements on behalf of the state may be pursued (or abandoned) fall within this area.

Three recent cases in South Africa illustrate some of the contestations that may play themselves out over the limits of the right to engage in foreign relations. The judgments in question are the Democratic Alliance v. Minister of International Relations and Cooperation concerning the decision of the government to withdraw from the Rome Statute (hereinafter the Withdrawal judgment), ${ }^{1}$ Law Society of South Africa v. President of South Africa (hereinafter the SADC Tribunal judgment), ${ }^{2}$ and Democratic Alliance v. Minister of International Relations and Cooperation concerning the decision of the government to confer or recognise spousal immunities of Grace Mugabe, the spouse of former late President of Zimbabwe (hereinafter the Grace Mugabe decision). ${ }^{3}$ While all three judgments addressed international law questions,

1 Democratic Alliance v. Minister of International Relations and Cooperation and Others 2017 (3) SA 212 (GP).

2 Law Society of South Africa and Others v. President of the Republic of South Africa and Others 2019 (3) BCLR 329 (CC).

3 Democratic Alliance v. Minister of International Relations and Co-operation and Others 2018 (6) SA 109 (GP). 
these international law questions were not the central legal questions to the disputes. Rather, the central questions in all three cases concerned the distribution of competence between branches of government in relation to the conduct of foreign relations - constitutional lawyers may refer to the doctrine of the 'separation of powers'. These judgments have a number of things in common. First, all three concern the powers of the executive in foreign relations, and the limits thereof. Second, all three judgments concern judicial review of decisions made by the executive during Zuma administration. Third, in the judgments, the courts came to the conclusion that the decisions by the executive had been unlawful. In the interest of full disclosure, I should declare that I had been involved in some way in all three matters before the courts - I will describe my personal involvement when discussing each case. Given space constraints, I will discuss the Constitutional Court judgment in the SADC Tribunal in detail and only briefly touch upon the other two, which were not delivered by the apex court.

The decisions, to varying degrees, reflect an interesting trend in which the courts have slowly but surely eroded the discretion of the executive in foreign relations to the point where it can hardly be termed discretion. Much of this erosion has developed, it seems, because of a mistrust of the Zuma administration, leading one commentator in a social media platform to quip that South Africa has a 'constitution written for a President like Mandela and a constitutional jurisprudence made for a President like Jacob Zuma'. ${ }^{4}$ This chapter will assess the decisions emanating from these cases principally from the perspective of the distribution of competence in the conduct of foreign relations. It proceeds from two premises which, decisions in question notwithstanding, have not been challenged as doctrine and remain, at least in rhetoric, the law in South Africa. First, the executive, even in the conduct of foreign relations, is constrained by the Constitution and the courts are not only permitted, but are duty-bound, to determine whether the executive has consistently with the Constitution. Second, while the courts are tasked with holding the executive accountable for its exercise of public power, the executive has a wide margin of discretion which ought not be interfered with lightly. In the next section of this chapter, the basis of these two premises is traced.

4 The phrase 'A Constitution made for a President like Mandela and a constitutional jurisprudence made for a President like Zuma' is borrowed from a facebook post by the recently appointed director of the Centre for Applied Legal Studies, Tshepo Mandlingozi. 


\section{MANDELA'S CONSTITUTION: EXECUTIVE DISCRETION IN FOREIGN RELATIONS}

South African courts, in the Apartheid years - before the international lawfriendly years 5 - applied British concepts such as 'the act of state doctrine' and the related 'prerogatives' in matters pertaining to the conduct of foreign relations by the executive, with the result that the executive's conduct was beyond review. Under these traditional concepts, the executive had an almost unfettered discretion in the conduct of foreign relations, ${ }^{6}$ and, in order to avoid judicial intrusion into the domain of the political branches', courts were required 'to refrain from sitting in judgment on the acts' covered by such doctrines. ${ }^{7}$ These concepts however, do not fit neatly into South Africa's constitutional model which, in addition to being an international lawfriendly framework, has also been termed a deliberative constitution. ${ }^{8}$ Under this constitutional framework all exercise of public power, including the executive's conduct of foreign relations, must be subject to judicial scrutiny to ensure compliance with the Constitution. ${ }^{9}$ This important constitutional principle raises the question of the appropriate standard for the review of the executive's conduct in matters of foreign relations.

In my view, the question was appropriately answered in a well-reasoned and rigorous judgment by the Constitutional Court in Kaunda v. the President of the Republic of South Africa. ${ }^{10}$ In Kaunda the court determined that though courts are entitled to review decisions of the executive in the exercise of its

5 For the description of the South African constitutional framework as international law-friendly see Neville Botha, 'Justice Sachs and the Interpretation of International Law by the Constitutional Court: Equity or Expediency?' (2010) 25 Southern Africans Public Law 235-50. See Dire Tladi, 'Interpretation of Treaties in an International Law-Friendly Framework: The Case of South Africa', in Helmut Aust and Georg Nolte (eds.), The Interpretation of International Law by Domestic Courts: Uniformity, Diversity, Convergence (Oxford: Oxford University Press, 2016).

6 See e.g. Michael Bayzler, 'Abolishing the Act of State Doctine' (1986) 134 University of Pennsylvania Law Review 325-98; David Gordon, "The Origin and Development of the Act of State Doctrine' (1976-1977) 8 Rutgers Camden Law Journal 595-616, at 595 ('As early as 1674, English courts declined to rule on the validity of foreign acts of state. This policy was adopted by the United States Supreme Court only twenty years after the Court's inception').

7 Mark Haugen and Jeff Good, 'Evolution of the Act of State Doctrine: W.S. Kirkpatrick Co. v. Environmental Tectonics Corp. and Beyond' (1991) 13 University of Hawaii Law Review $687-714$ at 688.

8 See Dikgang Moseneke, "Transformative Constitutionalism: its Implications for the Law of Contract' (2009) 20 Stellenbosch Law Review 3-13.

9 The President of the Republic of South Africa and Another v. Hugo 1997 (4) SA 1 (CC), at para. 13.

10 Kaunda and Others v. the President of the Republic of South Africa and Others 2005 (4) SA 235 (CC). For discussion of Kaunda see Dire Tladi and Polina Dlagnekova, "The Act of State 
mandate in foreign relations, in doing so they should 'give particular weight to the government's special responsibility for and particular expertise in foreign affairs' and therefore afford 'wide discretion ... in determining how to deal' with such foreign relations matters. ${ }^{11}$ According to the Constitutional Court, the courts could, for example, intervene if a decision was irrational. ${ }^{12}$ Importantly, the court stressed that the fact that the courts could review a decision of the executive in the conduct of foreign relations did 'not mean that courts would substitute their opinion for that of government' or order a particular course of action in the conduct of foreign relations. ${ }^{13}$

There is a second principle laid out in Kaunda which may be of some relevance for some of the analysis in this chapter. In rendering its decision, the court considered whether the Bill of Rights in the Constitution applies extraterritorially - this is referred to in the court's decision as extraterritoriality in a constitutional context. ${ }^{14}$ The court stated that the Constitution "provides a framework for the governance of South Africa', is 'territorially bound and has no application beyond our borders'. ${ }^{15}$ Foreigners are entitled to the protection offered by the constitution while in South Africa but lose any such protection "when they move beyond the borders'. ${ }^{16}$ The court emphasised that the 'bearers of the rights [in the constitution] are people in South Africa' and that " $n]$ othing suggests that it is to have general application, beyond our borders'. ${ }^{17}$

Doctrine in South Africa: Has Kaunda Settled a Vexing Question?' (2007) 22 South African Public Law 444-56.

${ }^{11}$ Kaunda and Others v. the President of the Republic of South Africa and Others 2005 (4) SA 235 (CC), at para. 144. Elsewhere the Court stated quoted with approval, a judgment in the German Federal Constitutional Court in the Hess decision BVerfGE 55, 349-70, at 395-6:

‘... the Federal Basic Law grants the organs of foreign affairs wide room for manoeuvre in the assessment of foreign policy issues....

12 Kaunda and Others v. the President of the Republic of South Africa and Others 2005 (4) SA 235 (CC), at para. 79 .

13 Kaunda and Others v. the President of the Republic of South Africa and Others 2005 (4) SA 235 (CC), at para. 79 .

14 Kaunda and Others v. the President of the Republic of South Africa and Others 2005 (4) SA 235 (CC), at para. 36 .

15 Kaunda and Others v. the President of the Republic of South Africa and Others 2005 (4) SA 235 (CC), at para. 36 .

16 Kaunda and Others v. the President of the Republic of South Africa and Others 2005 (4) SA 235 (CC), at para. 36 .

17 Kaunda and Others v. the President of the Republic of South Africa and Others 2005 (4) SA 235 (CC), at para. 37. At para. 54, in a slightly different, but still relevant, context, the Court noted that the Bill of Rights 'binds the South African government, but does not bind other governments'. 
Although Kaunda was decided during the presidency of Thabo Mbeki, it was built on jurisprudence developed under the Mandela administration. ${ }^{18}$ This jurisprudence not only advanced as a matter of principle (rhetoric) the idea of discretion and the notion that the courts ought to not substitute their own opinion for that of government, but actually applied said principle. The only time, during the Mandela-Mbeki administrations, when the rhetoric appeared not to be followed was in the Von Abo cases - which incidentally has interesting backstory connection with Law Society of South Africa v. President. ${ }^{19}$ The Von Abo cases are interesting series of cases in which one man, Von Abo, sued the government for failing to protect his farming and business interests in Zimbabwe. The North Gauteng High Court, though paying lip-service to the jurisprudence of Kaunda, found that the government was indeed duty-bound to intervene diplomatically to protect the commercial interests of $\mathrm{Mr}$ Von Abo in Zimbabwe. ${ }^{20}$ In a subsequent judgment on the damages, the Pretoria High Court proceeded to hold the government accountable on the basis of, inter alia, the failure to enter into a bilateral investment agreement with Zimbabwe (Von Abo II). ${ }^{21}$

Although the Pretoria High Court judgments in the Von Abo cases were eventually overturned by the Supreme Court of Appeal for not being consistent with the standard for the judicial review of acts of the executive in the conduct of foreign relations set by the Constitutional Court in, inter alia, Kaunda ${ }^{22}$ it is worth describing the salient themes of the Von Abo High Court judgments which, it seems, have been adopted in the new constitutional jurisprudence on the test for executive decisions in the conduct of foreign relations. The applicant in Von Abo had sought an order, inter alia, requiring

It was built in particular on the jurisprudence on the appropriate test for executive decisions such as The President of the Republic of South Africa and Another v. Hugo 1997 (4) SA 1 (CC) and President of the Republic of South Africa and Others v. South African Rugby Football Union and Others 2000 (1) SA 1 (CC) and Mohamed and Another v. President of the Republic of South Africa and Others 2001 (3) SA 893 (CC), although the latter concerned events that took place a few months after the end of the Mandela presidency.

19 See Law Society of South Africa and Others v. President of the Republic of South Africa and Others 2019 (3) BCLR 329 (CC).

20 Von Abo v. the Government of the Republic of South Africa and Others [2008] ZAGPHC 226. This judgment was the subject of a critique in Dire Tladi, "The Right to Diplomatic Protection, the Von Abo Decision and One Big Can of Worms: Eroding the Clarity of Kaunda' (2009) 1 Stellenbosch Law Review 14-30. When approached to confirm the order of the High Court, the Constitutional Court declined on account of procedural grounds not related to the substance. See Von Abo v. the President of the Republic of South Africa 2009 (5) SA 345 (CC).

${ }_{21}$ Von Abo v. the Government of the Republic of South Africa and Others 2010 (3) SA 269 (T).

22 Government of the Republic of South Africa and Others v. Von Abo 2011 (5) SA 262 (SCA). 
the government to, within thirty days, 'take all necessary steps to have the Applicant's violation of his rights by the Government of Zimbabwe remedied', ${ }^{23}$ remedies that the court granted in whole. There had also been a prayer, which was eventually abandoned by the Applicant but which the Court still felt the need to address, namely to 'force the respondent to join ICSID' - a treaty regime for the settlement of investment dispute. ${ }^{24}$ Both of these prayers seem to be far-reaching, policy matters concerning the conduct of foreign relations.

Although the Applicant had abandoned its prayer concerning ICSID, the Court nonetheless proceeds identify reasons why the government should join ICSID. ${ }^{25}$ These are policy consideration that courts are ill-equipped to consider. For example, while noting that joining ICSID would be greatly beneficial to South Africans investing in foreign states, ${ }^{26}$ it does not consider that joining ICSID opens South Africa to suit from investors from other states that might challenge basic foundational policies of the government such as Black Economic Empowerment. The court felt so strongly about this policy question of joining ICSID that, notwithstanding the abandonment of the prayer by the Applicant, it decided to keep it on the table:

The fact that the prayer for this specific relief was abandoned ... does not mean, in my view, that the consistent failure on the part of the respondents to join ICSID and make a serious attempt to enter into a Bilateral Investment Treaty ('BIT") with Zimbabwe with the view to protecting its nationals investing in that country should not come under the spotlight .... ${ }^{27}$

With respect to the broader question of intervening in executive decisions in the conduct of foreign relations, without assessing the appropriate standards in the particular case, the Court simply states that, on the basis of the 'guidelines' provided by the Constitutional Court in Kaunda, it appears that there need not be an actual refusal on the part of the Government to grant diplomatic protection before a court will intervene ... ${ }^{28}$ In assessing the judgment of the

23 Von Abo v. the Government of the Republic of South Africa and Others [2008] ZAGPHC 226, at para. 19 et seq.

24 Von Abo v. the Government of the Republic of South Africa and Others [2008] ZAGPHC 226 , para. 26.

25 Von Abo v. the Government of the Republic of South Africa and Others [2008] ZAGPHC 226, at paras. 29-37.

26 Von Abo v. the Government of the Republic of South Africa and Others [2008] ZAGPHC 226, at paras. 29 and 31 .

27 Von Abo v. the Government of the Republic of South Africa and Others [2008] ZAGPHC 226, at para. 37 .

28 Von Abo v. the Government of the Republic of South Africa and Others [2008] ZAGPHC 226, at para. 143 . 
Pretoria High Court in Von Abo, I have previously made the following general critique:

The judgment quotes large extracts from the Kaunda majority [judgment], dissenting and concurring [opinions], mixes them together in a potpourri approach and then declares an outcome. The congruence between this outcome and Kaunda is assumed and therefore never properly examined. The differences between the majority, minority and concurring [opinions] are never explored. ${ }^{29}$

The essence of Von Abo, contrary to the majority in Kaunda, is that the Government has a duty to provide diplomatic protection. Not only that, the court in Von Abo orders very specific ways to achieve this objective, including seeking a bilateral investment treaty or joining ICSID, in a way that makes nonsense of the Kaunda judgment's call for wide discretion because of the nature of the playing arena, namely foreign relations. As noted, this judgment was eventually overturned by the Supreme Court of Appeal for its failure to respect the wide margin of discretion required by Kaunda. ${ }^{30}$ This respect for the discretion of the executive in foreign relations has not meant that the courts have simply found in favour of the executive. In instances where the executive has clearly violated the constitution, the courts have not been shy to appropriately censure the executive. ${ }^{31}$

\section{ZUMA'S CONSTITUTIONAL JURISPRUDENCE: DISCRETION? WHAT DISCRETION?}

\section{A The SADC Tribunal Decision}

I begin with the SADC Tribunal judgment, first because it was delivered by the Constitutional Court and second because of the three decisions, it is the most problematic and the one whose reasoning most offends the Kaunda doctrine of a very wide margin of discretion in foreign relations. The SADC Tribunal judgment concerned the decision of the Southern African Development Community (SADC) heads of state and government to remove

29 Tladi, 'The Right to Diplomatic Protection', 24.

30 Government of the Republic of South Africa and Others v. Von Abo 2011 (5) SA 262 (SCA).

${ }^{31}$ For an example of a decision in which the Court held that the conduct of the executive in foreign relations was unconstitutional is Mohamed and Another v. President of the Republic of South Africa 2001 (3) SA 893 (CC) where the court held that the decision to render a Tanzanian national to the United States where he was subject to the possibility of the death sentence was contrary to the Constitution. 
the right of access to the SADC Tribunal for individuals and other non-state entities. The Constitutional Court was approached by the Law Society of South Africa and others seeking an order to find that the president of South Africa, by signing the protocol establishing a new tribunal without such access had violated the constitution. In a hard-to-follow judgment penned by the chief justice, Mogoeng Mogoeng, the court found that the president's participation in the 'decision-making process and his own decision to suspend the operations' of the tribunal to be unconstitutional, unlawful and irrational. ${ }^{22}$ The judgment also found that president's signing of the 2014 Protocol $^{33}$ was unconstitutional, unlawful and irrational and the court, as a result, directed the president to withdraw his signature. ${ }^{34} \mathrm{My}$ criticism of the judgment relates not only to the outcome, but to the reasoning, and to this point it may be added that a judgment built around the concurring opinion of justices Cameron and Froneman would be less objectionable, but ultimately also problematic. ${ }^{35}$

There is much that is open to critique - and little saving grace - in the SADC Tribunal judgment, both in terms of the order and the reasoning. But before delving into the analysis of the judgment, a related case concerning a South African diamond mining company, Swissbourgh, whose mineral rights in Lesotho had allegedly been expropriated to make way for the Lesotho Highlands Water Project, is worth referring to. The owner of the company, Mr Josias van Zyl, a South African national, first approached the South African courts (in the pre-Zuma years) seeking diplomatic protection, but was unsuccessful. ${ }^{36}$ The cases are related to the SADC Tribunal judgment because, subsequent to the impugned decision of the SADC Summit concerning the tribunal, Swissbourgh filed an investment claim with the Permanent Court of Arbitration against the government of Lesotho claiming that its participation in the decision-making process that led to the taking away of the right of individual access to the SADC Tribunal - referred to in all the

32 Law Society of South Africa and Others v. President of the Republic of South Africa and Others 2019 (3) BCLR 329 (CC), para. 97.

33 Protocol on the Tribunal in the Southern African Development Community adopted on 21 February 2014, available at https://ijrcenter.org/wp-content/uploads/2016/11/New-SADCTribunal-Protocol-Signed.pdf, accessed 30 September 2020. There has not yet been ratification by Parliament of this Protocol pursuant to the President's signature.

34 Law Society of South Africa and Others v. President of the Republic of South Africa and Others 2019 (3) BCLR 329 (CC), para. 97.

35 Law Society of South Africa and Others v. President of the Republic of South Africa and Others 2019 (3) BCLR 329 (CC), para. 97; concurring opinion judges Cameron and Froneman, paras. 98-104.

${ }^{6}$ Van Zyl and Others v. the Government of the Republic of South Africa and Others 2008 (3) SA 294 (SCA). 
relevant papers of those papers as the 'shuttering of the Tribunal' - was a violation of its rights under the SADC Treaty regime, including the investment protocol. It will be noted that the claims of Swissbourgh are similar to those raised by South African Law Society before the South African courts. In the Swissbourgh matter, I served as expert witness for the government of Lesotho, focusing on the rules of state responsibility under international law and the decision-making processes in SADC, providing both a written report and being cross-examined by counsel for Swissbourgh. ${ }^{37}$ In a majority judgment of two to one, the arbitral tribunal determined that Lesotho's participation in the decision-making process to shutter the tribunal did constitute a violation of international law and that Lesotho could be held liable for the damages ${ }^{3}$ - incidentally, the one dissenting opinion came from a former South African judge of appeal, judge Petrus Millar Nienaber. ${ }^{39}$ Because the arbitration was held under the PCA rules, the courts of Singapore had jurisdiction to review the arbitration award to determine whether the arbitral tribunal had jurisdiction. Lesotho had argued, inter alia, that the arbitral tribunal had not had jurisdiction precisely because its participation in the decision-making process did not establish international responsibility. After an earlier high court judgment affirmed Lesotho's claim, the highest court of Singapore, the Court of Appeal, finally overturned the arbitral award on the basis, inter alia, that the participation of Lesotho in the SADC decisions did not breach the relevant of international law as had been argued by Swissbourgh. ${ }^{4^{\circ}}$

Consistent with the Kaunda jurisprudence, the SADC Tribunal judgment begins by acknowledging that while public power must always be exercised within constitutional bounds, the president ought not to be 'unnecessarily constrained in the exercise of constitutional power' ${ }^{41}$ Yet, in what follows, the court departs from the Kaunda line of reasoning in at least two material ways.

37 The expert report is on file.

$3^{8}$ Swissbourgh Diamond Mines and Others v. the Kingdom of Lesotho, Permanent Court of Arbitration Case-2013-29, Partial Final Award on Merits and Jurisdiction, 18 April 2016. The judgment remains confidential but is on file with the author. I am able to share the outcome because, due to the appeals process in the courts of Singapore described further below, the outcome is for all intents and purposes, public.

39 Swissbourgh Diamond Mines and Others v. the Kingdom of Lesotho, Permanent Court of Arbitration Case-2013-29, Partial Final Award on Merits and Jurisdiction, 18 April 2016, dissenting opinion Justice Petrus Millar Nienaber.

$4 \circ$ See Swissbourgh Diamond Mining Company and Others v. the Kingdom of Lesotho, Court of Appeal of Singapore, 27 November 2018. For an accessible summary, see "Top court dismisses appeal on arbitration award', www.straitstimes.com/singapore/courts-crime/top-courtdismisses-appeal-on-arbitration-award <30 September 2020>.

${ }^{41}$ Law Society of South Africa and Others v. President of the Republic of South Africa and Others 2019 (3) BCLR 329 (CC), at para. 2. 
First, the court's reasoning seems to imply that the executive, when acting in foreign relations, should do so in a manner that protects fundamental rights extraterritorially. Second, the court's judgment, both in terms of its reasoning and in terms of dispositif leaves very little discretion for the executive.

The extraterritorial rationale of the court's judgment is evident early on when it states that the 'only avenue open to those [in Zimbabwe] aggrieved by having been deprived of their land in that constitutionally sanctioned manner was the Tribunal'. ${ }^{22}$ The court then states that the 'President, together with leaders of other SADC [states], decided to eviscerate the possibility of the states ever being held to account for perceived human rights violations, non-adherence to the rule of law or undemocratic practices'. ${ }^{43}$ For this reason the court states, that South Africa, through the actions of its president, "were party to denying citizens of South Africa and other SADC countries access to justice at a regional level'. ${ }^{44}$ Yet, leaving aside that this statement is made before any analysis of the issues takes place, this seems to go against Kaunda's admonition that the 'bearers of the rights [in the Constitution] are people in South Africa' and that '[n]othing suggests that it is to have general application, beyond our borders'. 45 The impugned decisions are decisions taken at an international forum, in a foreign country, with no apparent impact in South Africa at all. The extraterritorial nature of the conduct is buttressed by the assertion that the unconstitutionality flows from an alleged breach of a rule under international law.

The judgment, furthermore, leaves very little discretion, if any, for the executive in the conduct of foreign relations. The judgment's conclusions that the impugned decisions are unlawful, irrational and unconstitutional are based on a single pillar, namely that they are in breach of South Africa's international law obligations. Given the far reaching nature of the decision - constraining the executive's role in international forums and even declaring the signature of a treaty to be unlawful one would have expected a detailed and rigorous assessment of the claim that the impugned decisions were in breach of international law. ${ }^{6}$ Yet there is no assessment of this claim at all.

42 Law Society of South Africa and Others v. President of the Republic of South Africa and Others 2019 (3) BCLR 329 (CC), para. 11.

43 Law Society of South Africa and Others v. President of the Republic of South Africa and Others 2019 (3) BCLR 329 (CC), at para. 14 (emphasis added).

44 Law Society of South Africa and Others v. President of the Republic of South Africa and Others 2019 (3) BCLR 329 (CC), at para. 15.

45 Kaunda and Others v. the President of the Republic of South Africa and Others 2005 (4) SA 235 (CC), at para. 37 .

$4^{6}$ A more detailed analysis of the international law questions in the judgment can be found in a forthcoming article Dire Tladi, 'The Constitutional Court's Judgment in the SADC Case: International Law Continues to Befuddle' (2020) 10 Constitutional Court Review 129-43. 
There appears to be two possible bases, none of which are really tested, for the court's assertion that the treaty has been breached. The first is what the court refers to as the entrenchment of a human rights culture, a democratic order and adherence to the rule of law' and the obligation on the SADC summit not to disturb these values. ${ }^{47}$ The content of this 'obligation' is never described nor is it ever explained how the decision to adopt the 2014 Protocol breaches this obligation. In other words, does this 'entrenchment-obligation' require the existence of a tribunal in which individuals will have direct access? This certainly does not go without saying since the UN Charter itself has a human rights-entrenchment clause, ${ }^{48}$ yet the UN does not have a tribunal with the right of access of all individuals of UN member states. The closest the court comes to any sort of description, let alone analysis, of this 'obligation' is a footnote reference to article 4 of the treaty and the preamble. Yet, article 4 of the treaty simply provides that the SADC and its member states shall act in accordance with a number of enumerated principles, including 'human rights, democracy and the rule of law'. ${ }^{49}$ None of these principles imply, let alone require, the existence of a tribunal, even less so one with the right of individual access.

To the extent that article 4 (c) might be said to refer to a right of access to an effective judicial remedy under international law, this is a right that applies in national systems. There is no right, whether under the SADC Treaty ${ }^{\circ}$ or general international law, to access to an international tribunal (I include regional courts under the rubric of international courts)..$^{51}$ It is disconcerting 2019 (3) BCLR 329 (CC), at para. 51.

$4^{8}$ See e.g. arts. 55 and 56 of the Charter of the United Nations, San Francisco, 26 June 1945, 1 UNTS XVI.

49 See especially art. 4(c) of the Treaty of the Southern African Development Community.

50 Treaty of the Southern African Development Community, Windhoek, 17 August 1992, available at www.sadc.int/files/5314/4559/5701/Consolidated_Text_of_the_SADC_Treaty_-_scan ned_21_October_2015.pdf, accessed 30 September 2020.

51 See e.g. United Nations Human Rights Committee, General Comment No. 32 - Article 14: Right to equality before courts and tribunals and to a fair trial, CCPR/C/GC/32, 23 August 2007, commenting on article 14 of the International Covenant on Civil and Political Rights: "This guarantee not only applies to courts and tribunals addressed in the second sentence of this paragraph of article 14, but must also be respected whenever domestic law entrusts a judicial body with a judicial task' (para. 7); see also para. 18, which states: "The notion of a "tribunal" in article 14, paragraph 1 designates a body, regardless of its denomination, that is established by law, is independent of the executive and legislative branches of government or enjoys in specific cases judicial independence in deciding legal matters in proceedings that are judicial in nature. ...' (emphasis added) and the '... failure of a State party to establish a competent tribunal to determine such rights and obligations or to allow access to such a tribunal in specific cases would amount to a violation of article 14 if such 
that the court seems oblivious to, or perhaps simply chose to ignore, the fact that the African Commission of Human and Peoples Rights had recently addressed the question of whether the shuttering of the tribunal's access to individuals amounted to a breach of the right of access to courts and effective judicial remedies in an application filed by Luke Munyandu Tembani who, incidentally was also second applicant in the Constitutional Court application. ${ }^{52}$ In its well-reasoned decision, the African Commission concludes that the right of access to courts applied to national courts and not to international courts and, therefore, that the impugned decision of the SADC Summit was not contrary to the right of access to courts. ${ }^{53}$

The second possible basis for the conclusion that the impugned decision was a breach of South Africa's international law obligation is that the SADC summit did not follow the appropriate procedures under the relevant SADC treaties. According to the court, the adoption of the new 2014 Protocol was unlawful because 'the Treaty has never been amended so as to repeal its provisions relating to individual access to the Tribunal, human rights, the rule of law and access to justice'. ${ }^{54}$ In the view of the court, the jurisdiction of the Court could only be "lawfully tampered with in terms of the provisions of the [SADC] Treaty that regulate (sic) its amendment'. ${ }^{55}$ The SADC Treaty, and indeed other SADC instruments including the 2001 Protocol $^{56}$

limitations are not based on domestic legislation, are not necessary to pursue legitimate aims such as the proper administration of justice, or are based on exceptions from jurisdiction deriving from international law such, for example, as immunities, or if the access left to an individual would be limited to an extent that would undermine the very essence of the right' (emphasis added). See also art. 8 of the 1948 Universal Declaration of Human Rights is instructive in this respect. It provides that everyone 'has the right to an effective remedy by the competent national tribunals for acts violating the fundamental rights', UN General Assembly, Universal Declaration of Human Rights, 10 December 1948, 217 A (III); art. 13 of the European Convention on Human Rights provides for the right to an 'effective remedy before a national authority', Convention for the Protection of Human Rights and Fundamental Freedoms, Rome, 4 November 1950, 213 UNTS 221.

52 Luke Munyandu Tembani and Benjamin John Freeth (represented by Norman Tjombe) v. Angola and Thirteen Others, Communication 409/12, www.achpr.org/public/Document/fi le/English/achpr54_409_12_eng.pdf <30 September 2020>.

53 Luke Munyandu Tembani and Benjamin John Freeth (represented by Norman Tjombe) v. Angola and Thirteen Others, Communication 409/12, www.achpr.org/public/Document/fi le/English/achpr54_409_12_eng.pdf <30 September 2020>, at paras. 139, 144 and 146.

54 Law Society of South Africa and Others v. President of the Republic of South Africa and Others 2019 (3) BCLR 329 (CC), para. 53.

55 Law Society of South Africa and Others v. President of the Republic of South Africa and Others 2019 (3) BCLR 329 (CC), para. 49.

56 Protocol on Tribunal in the Southern African Development Community, Windhoek, 7 August 2000, www.sadc.int/files/1413/5292/8369/Protocol_on_the_Tribunal_and_Rules_the reof2000.pdf, accessed 23 September 2020. 
establishing the tribunal, require a two-third majority for amendment and dissolution of any SADC institutions. ${ }^{57}$ Yet the court, beyond stating that the SADC instruments required a two-thirds majority, does not test whether the procedures under the SADC instruments were complied with or not. The closest to any kind of assessment of whether the impugned decisions were made in accordance with a procedure that was consistent with the relevant instruments is the assertion by the Court that instead of the "three quarters majority', the Summit 'sought to amend the Treaty through a protocol, thus evading compliance with the Treaty's more rigorous threshold of threequarters of all of its Member States'. ${ }^{5}$ It states, without explanation, that the decision of SADC 'evidences a failure to adhere to the provisions or proper meaning of the Treaty', ${ }^{59}$ without applying the methodology for treaty interpretation under international law.

An assessment of the adherence to the procedure of the SADC summit would require, first, an interpretation of the relevant instruments and second, the description of the procedure followed. The court does neither of these. It is the case that the while instruments require a two-thirds majority, the impugned decision by SADC was adopted by consensus. Whether the consensus procedure falls foul of the two-thirds majority requirement is a matter to be determined through interpretation. This is particularly the case since SADC only ever adopts decisions by consensus, even where a two-thirds majority is required. ${ }^{60}$ This consensus-decision-making-process arguably

57 See art. 36(1) of the SADC-Treaty provides that an amendment of the treaty 'shall be adopted by a decision of three-quarters of all Members of the Summit'. Art. 37(3) Protocol of the Tribunal in the Southern African Development Community, Windhoek, 7 August 2000, www.sadc.int/files/ 1413/5292/8369/Protocol_on_the_Tribunal_and_Rules_thereof2000.pdf, <30 September 2020>, states that " $\mathrm{a}] \mathrm{n}$ amendment to this Protocol shall be adopted by a three (3) quarters of all the members of the Summit .... Moreover, the SADC-Treaty provides that Art. 22(11) provides that " $[\mathrm{a}] \mathrm{n}$ amendment to any Protocol that has entered into force shall be adopted by a decision of three-quarters of the Member States that are Party to the Protocol'. Article 37(3) of the 2000 Protocol.

$5^{8}$ Law Society of South Africa and Others v. President of the Republic of South Africa and Others 2019 (3) BCLR 329 (CC), at para. 49. See also at para. 52 ("More importantly, the Tribunal is an institution of SADC and the Treaty requires a "resolution supported by three-quarters of all members to dissolve ... any institution"').

59 Law Society of South Africa and Others v. President of the Republic of South Africa and Others 2019 (3) BCLR 329 (CC), at para. 51.

6. See e.g. para. 8.2.4.1 of the Records of the Summit Decision of August 2007 amending the Tribunal Protocol to 'facilitate trade disputes in the SADC Region'; Decision 6 of the Records of the Summit Decision of August 2008 amending the Treaty to provide for two Deputy Executive Secretaries and the abolition of the Integrated Committee of Ministers; Decision 10 on the Amendment of Article 6 of the Tribunal Protocol; Summit Decision 15 on the amendment of SADC Treaty so as not to provide for a specific number of Deputy 
constitutes subsequent practice within the meaning of article $31(3)$ (b) of the Vienna Convention, which should be taken into account in determining whether the SADC decisions are consistent with the relevant instruments. ${ }^{6}$ As the International Law Commission has noted, subsequent practice under article 31(3)(b) of the Vienna Convention 'may serve to clarify the meaning of a treaty by narrowing, widening or otherwise determining the range of possible interpretations, including any scope for the exercise of discretion which the treaty accords to the parties'. ${ }^{62}$ It is worth mentioning that the Constitutional Court itself, in Zimbabwe v. Fick, accepted without question the amendment to article 16 of the SADC Treaty (concerning the tribunal), even though that amendment was adopted by consensus and not by a recorded vote. ${ }^{6}$ There is thus a settled practice, over an extended period of time, in which SADC member states have made decisions by consensus, even where the requisite treaty provides for a threshold of two-third majority. This would indicate that the impugned decisions were adopted consistently with the 'authentic'64 interpretation of parties to the SADC instruments which ought to have been taken into account in the assessment of whether those decisions were procedurally valid.

In addition to not considering the role of subsequent practice, the court also failed to consider that adopting a new treaty, even one inconsistent with a previous treaty is not unlawful under international law. As a general matter,

Executive Secretaries. See Compilation of Summit and Council Records of Decisions, available at www.sadc.int/documents-publications/show/7813, accessed 30 September 2020.

61 Article 31(3)(b) of the Vienna Convention on the Law of Treaties, Vienna, 23 May 1969, 1155 UNTS 331 .

62 ILC 2018, Draft Conclusions on Subsequent Agreements and Subsequent Practice in Relation to the Interpretation of Treaties, Report of the International Law Commission, Seventieth Session, General Assembly Official Records (A/73/10), Draft Conclusion 7.

63 The Government of the Republic of Zimbabwe v. Louis Karel Fick and Others, Case CCT 101/12 [2013] (10) BCLR 1103 (CC), at para. 10 ("The amendment alluded to above was effected by the Summit in terms of the Agreement Amending the Treaty of the Southern African Development Community (Amending Agreement). Article 16(2) of the Treaty was amended to provide for the Tribunal Protocol to be an integral part of the Treaty, obviously subject to the adoption of the Amending Agreement'.). See art. 18 of the 2001 Agreement Amending the Treaty of the Southern African Development Community. The Agreement was adopted on 14 August 2001. See Communiqué of the SADC Summit of 2001 August, Malawi Blantyre, para. 23.

64 See draft conclusion 3 of the ILC 2018 Draft Conclusions on Subsequent Agreements and Subsequent Practice in Relation to the Interpretation of Treaties, Report of the International Law Commission, Seventieth Session, General Assembly Official Records (A/73/10), ('Subsequent agreements and subsequent practice under article 31, para. 3 (a) and (b) [of the Vienna Convention], being objective means evidence of the understanding of the parties as to the meaning of the treaty, are authentic means of interpretation, in the application of the general rule of treaty interpretation in article $31^{\prime}$.). 
rules of international law, including treaty rules, are jus dispositivum and can be derogated from or modified by subsequent rules of international law. ${ }^{65}$ This includes treaty rules concerning access to courts and certainly includes rules of amendments. The only exception to this basic rule of international law is the operation of peremptory norms of general international law (jus cogens). ${ }^{66}$ It is clear that the court does not believe that the right of individual access to the SADC Tribunal is a peremptory norm since it accepts that the provisions could have been amended through the 'correct procedure'. Nor does the court assert that the amendment provisions themselves are of a peremptory character. This being the case, the normal rules of successive treaties laid out in the Vienna Convention would, even if in the absence of the application of article 31(3)(b), be relevant. Article 59 of the Vienna Convention provides for the termination of one treaty by entry into force of another if 'it appears from the later treaty or is otherwise established' that the parties to the previous treaty intend for it to be replaced. ${ }^{67}$ This rule is not subject to the provisions of the previous treaty. ${ }^{68}$ The 2014 Protocol is explicit that the 2000 Protocol is replaced with effect from the date of entry into force of the 2014 Protocol. ${ }^{69}$ Even though the 2014 Protocol is inconsistent with the 2000 Protocol, it is hard to imagine how the adoption of a subsequent treaty repealing an old treaty a situation contemplated by the Vienna Convention - could be unlawful. At any rate, the problem with the Court is not only its conclusion but also its failure to engage with the methodology of international law by addressing this and other rules of interpretation.

It is hard to imagine what policy space, or discretion, is left for the executive, after the SADC Tribunal judgment. To borrow from the words of Kaunda the Constitutional Court does not 'give particular weight to the government's special responsibility for and particular expertise in foreign affairs' and certainly does not afford it 'wide discretion ... in determining how to deal'.

65 North Sea Continental Shelf cases (Federal Republic of Germany/Denmark; Federal Republic of Germany/Netherlands), I.C.J. Reports 1969, p. 3, para. 72. See for discussion First Report of Special Rapporteur (Dire Tladi) on Jus Cogens (A/CN.4/793), paras. 66-7.

66 North Sea Continental Shelf cases (Federal Republic of Germany/Denmark; Federal Republic of Germany/Netherlands), I.C.J. Reports 1969, p. 3, para. 72. See for discussion First Report of Special Rapporteur (Dire Tladi) on Jus Cogens (A/CN.4/793), paras. 66-7. See also generally, Draft Conclusions on Peremptory Norms of General International Law (Jus Cogens), Report of the International Law, General Assembly Official Records (A/74/10), 147.

67 Article 59 of the Vienna Convention ('A treaty shall be considered terminated if all the parties to it conclude a later treaty relating to the same subject and ... [it] appears from the later treaty or is otherwise established that the parties intended that the subject matter be governed by that treaty ...').

68 See ibid.

69 Article 48 of the 2014 Protocol. 
Moreover, this judgment, again contrary to the admonition of Kaunda, substitutes its own policy preferences for those of the government: the government, as a policy matter, accepted the position of other SADC members to have a tribunal without individual access, but the court preferred a tribunal with such access. The judgment provides a good illustration for why courts should avoid replacing their own policy-preferences for the government's, particularly in the area of foreign relations. The judgment treats the executive's participation in the decision of 2012 to dissolve the SADC Tribunal as a simple choice between supporting the shuttering or not. It shows a complete ignorance for the fact that states have other choices, including not blocking consensus of decisions they are not fully supportive of, or of being agnostic. The court does not even grapple with the decision-making processes to determine whether there was a vote, or if the decisions were adopted by consensus, if there was a vote whether South Africa supported the motion or abstained. Under the SADC Tribunal judgment, the decision of the South Africa to support, abstain from or not support, a resolution in any organ of an international organisation, including the UN General Assembly, the United Nations Security and the African Union, can be overturned by the courts if the decision does not accord with the policy preferences of the court.

\section{B The Democratic Alliance cases}

The SADC Tribunal judgment is notable not only because it is handed down by the apex court, but also because of how far-reaching it is. The judgment concerned the type of decision that one would expect a court to give the greatest of discretion to the executive - one that took place outside the borders of the country, concerned organs of an international organisation and had little impact on South African law or South African circumstances. Yet the erosion of the discretion of the executive by the courts is not isolated. Two cases brought by the Democratic Alliance and decided by the High Courts of Gauteng - the Grace Mugabe and Withdrawal decision - provide further examples of decisions by courts concerning the exercise of discretion by the executive in foreign affairs.

The Grace Mugabe judgment concerned the decision of the South African foreign minister to confer immunities on Grace Mugabe, at the time the spouse of Robert Mugabe (then head of state of Zimbabwe). ${ }^{70}$ The decision emanated from the now infamous alleged assault by Grace Mugabe on

$7^{\circ}$ In the interest of transparency, I should declare that at the time of the relevant events, I served as Special Adviser to the foreign minister and was intimately involved in the decision-making. 
a South African woman, Gabriella Engels, in Johannesburg. The assault took place during the SADC summit of 2017 but before the arrival of Robert Mugabe - although there is some dispute as to whether Grace Mugabe was in South Africa for the summit or for personal reasons, this question is in fact immaterial to the legal issues and the question of the discretion. The decision was made pursuant to section $7(2)$ of the Diplomatic Immunities and Privileges $\mathrm{Act}^{71}$ which provides as follows:

The Minister may in any particular case if it is not expedient to enter into an agreement as contemplated in subsection ( 1 ) and if the conferment of immunities and privileges is in the interest of the Republic, confer such immunities and privileges on a person or organisation as may be specified by notice in the Gazette.

In the midst of a media storm surrounding the events, and in response to a note verbal from the Embassy of Zimbabwe, the minister conferred immunity on the First Lady in accordance with section $7(2)$ of the act. In a letter to the National Commission of Police, the Director-General of the Department of International Relations and Cooperation stated that the discretion accorded to the minister under the section was not absolute and required 'the Minister to consider all the facts and circumstances' and further noted that any decision she takes 'must be reasoned'..$^{2}$ The letter provides a detailed account of the facts and circumstances taken into account by the Minister, but these can be summarised as follows:

(i) the rule of law and the need to ensure that the law protected South African citizens;

(ii) that Grace Mugabe was the First Lady of neighbouring and that prosecuting her would negatively affect relations between South Africa and Zimbabwe and may even affect relations between South Africa and other African states;

(iii) that South Africa was chair of SADC and the ongoing SADC Summit would be thrust the SADC Summit into chaos if the First Lady were arrest and prosecuted; and

(iv) that under customary international law spouses of heads of state were entitled to derivative immunity.

${ }^{71}$ Diplomatic and Immunities Act, No. 37 of 2001, www.gov.za/sites/default/files/gcis_docu ment/201409/a37-010.pdf<30 September 2020>.

72 The full letter is quoted in Democratic Alliance v. Minister of International Relations and Cooperation and Others 2018 (6) SA 109 (GP), at para. 6. 
The court, however, declared that the decision of the minister was unconstitutional and set it aside it. First, it cast doubt on the assertion that spouses of heads of state are entitled to derivative immunity ratione personae. Although derivative immunity of the immediate family of a head of state, especially the spouse, is generally accepted, ${ }^{73}$ the court dismisses the contention on the basis that 'at least two other national courts' have rejected this view. ${ }^{74}$ Yet, both cases relied on by the court are not authority for the view that spouses of heads of state are not immune from the foreign criminal jurisdiction. First, the Belgian judgment in Mobutu v. SA Cotoni ${ }^{75}$ cited by the court did not concern immunity from criminal jurisdiction but rather immunity from civil jurisdiction. These two types of immunities are different and cannot just be conflated. ${ }^{76}$ An illustration of the fact that, as a matter of international law, the rules pertaining immunity in civil proceedings ought not to be simply transposed to immunity in criminal proceedings, is the Jurisdictional Immunities of States case, where the International Court of Justice, while concluding that there are no jus cogens exceptions to immunity from civil jurisdiction, noted that the same was not necessarily true for immunity from foreign criminal jurisdiction. ${ }^{77}$ This is not to say that rules relating to civil

73 See for discussion Joanne Foakes, The Position of Heads of State and Senior Officials in International Law (Oxford: Oxford University Press, 2014), p. 104. While there are discrepancies on the scope, what is not questioned is that spouses benefit from this type of immunity when in the company of the heads of State. See in this respect, Robert Jennings and Arthur Watts (eds.), Oppenheim's International Law, 9th ed., 2 vols. (Harlow: Longman, 1992), Vol. 1: Peace, Parts 2 to 4, 1039 et seq. ('[With respect to Family members], [e]xcept in so far as they may regarded as part of the Head of State's retinue, their exemption from [jurisdiction is] more questionable, except in the case of the Head of State's spouse') (emphasis added). See also Arthur Watts, "The Legal Position in International Law of Heads of States, Heads of Governments and Foreign Ministers' (1994) 247 Recuile de Cours de l'Académie de Droit International de La Haye 9-30.

74 Democratic Alliance v. Minister of International Relations and Co-operation and Others 2018 (6) SA 109 (GP), at para. 24.

75 Cited in Preliminary Report on Immunity of State Officials from Foreign Criminal Jurisdiction by Roman Kolodkin, Special Rapporteur (A/CN.4/604), 29 May 2008, at para. 126. I note that the High Court did not consult the judgment itself but rather relied on an account of the judgment offered in the Kolodkin report and erroneously suggested that the judgment was in German ('The judgment is in German. The summary herein is drawn from the report' of Roman Kolodkin).

$7^{6}$ See for discussion Third Report of the Special Rapporteur (Dire Tladi) on Peremptory Norms of General International Law (Jus Cogens) (A/CN.4/714), at para. 124.

77 Jurisdictional Immunities of the State (Germany v. Italy: Greece intervening), Judgment, I.C.J. Reports 2012, p. 99, para. 91 ("The Court concludes that, under customary international law as it presently stands, a State is not deprived of immunity by reason of the fact that is it is accused of serious violations of international human rights law or the international law of armed conflict. In reaching that conclusion, the Court must emphasise that it is addressing only the 
proceedings are not at relevant at all, since they have been used as a basis to define the head of state as including their spouses. ${ }^{78}$ Second, the Belgian court in the Mobutu case did not exclude derivative immunity of the immediate family. Rather, that Court excluded the children of the president of Zaire from the scope of such derivative because they had reached and passed the age of majority and, as such, were not his immediate family. The same is true of the other authority relied on, namely $W$ v. Prince of Liechtenstein, in which the Austrian Supreme Court denied derivative immunity. ${ }^{79}$ As in the Mobutu case, W v. Prince of Liechtenstein concerned civil immunity and, more importantly, derivative immunity was excluded not because the Court did not recognise its existence but rather because sisters and brothers of the head of state were not regarded as part of the immediate family. If anything, these authorities would support derivative immunity but restrict its scope of application to the immediate family, which the spouse of a head of state would most certainly be. The relevant part of paragraph 24 , in which these two cases are discussed, is in fact taken, verbatim from the preliminary report of the International law Commission Special Rapporteur on the topic of immunity (and sometimes without acknowledgement). ${ }^{80}$ However, the judgment is misleading and quotes the report out of context. In the report, in the preceding paragraph, the special rapporteur confirms the view of the minister that this "jurisdictional immunity . . . also extends, in such circumstances, to the closest accompanying family members .... ${ }^{81}$ Having referred to the two cases utilised as the only two cases in which derivative immunity was denied, ${ }^{82}$ the special rapporteur then places them in context by stating that in the two cases ... in which the courts declined to recognise the immunity of the' the relevant

immunity of the State itself from the jurisdiction of the courts of other States; the question of whether, and if so to what extent, immunity might apply in criminal proceedings against an official of the State is not in issue in the present case') and at para. 87, noting that the Pinochet case "concerned the immunity of a former Head of State from the criminal jurisdiction of another State, not the immunity of the State itself in proceedings designed to establish its liability to damages' (emphasis added). This similar sentiment has been expressed in other cases, e.g. Yousuf v. Samantar, 699 F.3d 763, 776-77 (4th Cir. 2012), at para. 124. See also ILC Summary Records, Tladi (A/CN.4/SR.3425), at 14.

$7^{8}$ Foakes, The Position of Heads of State, p. 104.

79 Cited in the Preliminary Report on Immunity of State Officials from Foreign Criminal Jurisdiction by Roman Kolodkin, Special Rapporteur (A/CN.4/604), 29 May 2008, at para. 126.

8o Preliminary Report on Immunity of State Officials from Foreign Criminal Jurisdiction by Roman Kolodkin, Special Rapporteur (A/CN.4/604), 29 May 2008, at para. 126.

${ }^{8}$ Preliminary Report on Immunity of State Officials from Foreign Criminal Jurisdiction by Roman Kolodkin, Special Rapporteur (A/CN.4/604), 29 May 2008, at para. 125.

82 Preliminary Report on Immunity of State Officials from Foreign Criminal Jurisdiction by Roman Kolodkin, Special Rapporteur (A/CN.4/604), 29 May 2008, at para. 126. 
family members 'the rulings were based on the fact that the persons concerned were not among the immediate family of the Head of State and were not dependent on him'. ${ }^{83}$ The court's use of these authorities is thus, at best a misunderstanding, and at worst a misrepresentation of the authorities in question. The false impression is also created in the judgment that the Kolodkin report rejected spousal immunity while the report clearly believed spousal immunity to be part of customary international law. ${ }^{84}$

The court's judgment is based on another significant error. The court relies on section 6(a) of the Foreign States Immunities Act which, according to the court, excludes the immunity of $\mathrm{Mr}$ Mugabe in cases of 'death or injury of any person'. ${ }^{85}$ If, so the understanding of the court goes, Robert Mugabe did not enjoy immunity because section 6(a) excludes of the Foreign States Immunities Act excludes immunity in the case of 'death or injury', then Grace Mugabe could not, herself, have enjoyed immunity as it was derivative. This reflects a complete lack of understanding not only of international law but of the immunity legislation in South Africa. Immunity ratione personae from foreign criminal jurisdiction is not addressed at all in the Foreign States Immunities Act which addresses the immunity of the state itself from civil proceedings. ${ }^{86}$ Immunity ratione personae from foreign criminal jurisdiction in South Africa is governed by the Diplomatic Immunities and Privileges Act ${ }^{87}$ and, as recognised by the Supreme Court, it knows no exception both under international law. ${ }^{88}$ According to the court, in the Al Bashir judgment, the only exception is the relation to International Criminal Court arrest and surrender proceedings. ${ }^{89}$

83 Preliminary Report on Immunity of State Officials from Foreign Criminal Jurisdiction by Roman Kolodkin, Special Rapporteur (A/CN.4/604), 29 May 2008, at para. 127.

84 Preliminary Report on Immunity of State Officials from Foreign Criminal Jurisdiction by Roman Kolodkin, Special Rapporteur (A/CN.4/604), 29 May 2008, at para. 127.

85 Democratic Alliance v. Minister of International Relations and Co-operation and Others 2018 (6) SA 109 (GP), at paras. 39-40.

86 See John Dugard. 'Immunity', in John Dugard et al., (eds.), Dugard's International Law: A South African Perspective, 5th ed. (Cape Town: Juta, 2018), p. 347 et seq.

87 Section 4(1)(a) of the Diplomatic Immunities and Privileges Act of 2001 provides that a head of State enjoys such immunity 'from the criminal and civil jurisdiction of the courts ... in accordance with rules of customary international law'. I note, though this is not critical, that even if the Foreign States Immunities Act were relevant, as the later law, the Diplomatic Immunities and Privilege would trump it.

88 Minister of Justice and Others v. South African Litigation Centre and Others 2016 (3) SA 317 (SCA).

89 Minister of Justice and Others v. South African Litigation Centre and Others 2016 (3) SA 317 (SCA). 
On the basis of these two flawed bases, the court decides to overturn a decision of the executive based on a discretion expressly granted by legislation. It does not even assess whether the discretion was exercised correctly. The discretion accorded to the executive in the conduct of foreign relations in Kaunda and confirmed by the Diplomatic Immunities and Privileges Act is ignored in favour of the policy preference of the judiciary. Let me pause to say, it is correct that at the time judgment Grace Mugabe did not, under customary international law, enjoy the derivative immunity referred to in the decision of the minister, because that immunity applies only to the spouse of a sitting head of state and when in the presence of the head of the state. The question is not whether Grace Mugabe had immunity or not, the question is whether the minister had the right, acting under the Diplomatic Immunities and Privileges Act and in the exercise of the executive competence in foreign relations, to confer such immunities.

The second Democratic Alliance case, the Withdrawal judgment, concerned the decision of the South African government to withdraw from the Rome Statute of the International Criminal Court without parliamentary approval. The reasoning in the Withdrawal judgment is not as objectionable as the SADC Tribunal and Grace Mugabe judgment. Indeed, though I don't fully agree with the decision, I believe it is a reasonable judgment and, at least on the surface, perhaps even more rational than what I believe is the objectively correct interpretation of the law. ${ }^{90}$ As the court stated, the Withdrawal judgment concerned 'the separation of powers between the national executive and parliament in international relations and treaty-making'.$^{91}$ In this case, the High Court determined that South Africa could withdraw from a treaty entered into after the approval of parliament, only after parliament itself had approved the withdrawal. According to the court, "there is no question that the power to conduct international relations and to conclude treaties has been

90 The relevant events also took place while I was adviser to the Foreign Minister. Here, I should say, my legal views were at variance with my political views. Contrary to my legal views, expressed in this chapter, my political views were as follows: First, given the judgment of the Supreme Court of Appeal in the Al Bashir judgment, it was unnecessary to withdraw. A careful reading of the $\mathrm{Al}$ Bashir judgment suggested that the problem was not the Rome Statute at all, but rather South Africa's domestic implementation legislation. Rather than withdraw, all South Africa needed to do was to amend it's the Rome Statute Implementation Act and its problems would disappear. If, however, it was deemed necessary to withdraw, parliamentary approval should be obtained because, while my legal position was that it was unnecessary, it was difficult to imagine a South African court accepting such an argument, even in the absence of the 'Zuma-jurisprudence'.

91 Democratic Alliance v. Minister of International Relations and Cooperation and Others 2017 (3) SA 212 (GP), at para. 1. 
constitutionally conferred upon the executive'. ${ }^{2}$ This power, however, is not unfettered and requires 'the national power to engage parliament'. ${ }^{93}$ In this context, it accepts that 'the formulation of a policy to withdraw from the Rome Statute therefore no doubt falls within the national executive's province'. ${ }^{94}$ However, in the view of the court, the 'approval of an international agreement' by parliament 'creates a social contract between the people of South Africa' and the national executive, requiring parliamentary approval before the executive seeks to withdraw from an agreement so approved. ${ }^{95}$

Although I do not share in this interpretation, I am not inclined to be too critical of this decision, nor would I ascribe it necessarily solely to the emergence of the 'Zuma jurisprudence'. This is because the reasoning seems logical and is not based on any obviously flawed logic. There is, however, an alternative construction of section $231(2)$ of the Constitution ${ }^{96}$ which would grant greater autonomy to the executive in the conduct of foreign relations for the record, this alternative interpretation was never presented by counsel for the government whose argument were rather convoluted. ${ }^{97}$ My own reading of section $231(2)$ is that it requires parliament to approve international agreements before the executive can ratify such agreements. Yet, the approval by parliament is nothing more than that - an approval or, to put it more colloquially, permission to ratify. The approval itself does not bind the republic to the obligation contained in the treaty nor does it bind the executive into ratifying the relevant treaty. The approval is intended to confirm that the treaty is consistent with South Africa's legal framework and that the executive may, if

92 Democratic Alliance v. Minister of International Relations and Cooperation and Others 2017 (3) SA 212 (GP), para. 35.

93 Democratic Alliance v. Minister of International Relations and Cooperation and Others 2017 (3) SA 212 (GP), at para. 35.

94 Democratic Alliance v. Minister of International Relations and Cooperation and Others 2017 (3) SA 212 (GP), at para. 45.

95 Democratic Alliance v. Minister of International Relations and Cooperation and Others 2017 (3) SA 212 (GP), at paras. 52 and 53.

96 Section 231 of the South African Constitution provides as follows: 'An international agreement binds the Republic only after it has been approved by a resolution in both the National Assembly and the National Council of Provinces ..., www.gov.za/sites/www.gov.za/files/images/a1o8-96 .pdf, accessed 30 September 2020 .

97 The government, in essence, argued that "parliament approval is only required in order for a treaty to become binding'. See, Democratic Alliance v. Minister of International Relations and Cooperation and Others 2017 (3) SA 212 (GP), at paras. 38-9. There was also a similarly confusing argument that a notice of withdrawal under international law does not require parliamentary approval (at para. 40). This latter point is accurate but irrelevant. The question was not whether the notice of withdrawal was valid under international law, surely it was. Rather the question was whether it was valid under domestic law. 
it wished, proceed with the ratification process. ${ }^{98}$ If approval is nothing more than permission to become party, then whether South Africa becomes a party to the said treaty or not, or becomes party and then decides to withdraw, does not undermine the parliamentary approval. To put it simply, parliamentary approval establishes a right to join the treaty not an obligation to become (or remain) a party. This, however, is only one possible approach to section 231(2)one which would give the executive greater discretion to make policy choices in foreign relations - and the Court chose another, equally reasonable approach.

\section{CONCLUSION}

Under the South African constitutional framework, all exercise of public power is subject to judicial review to ensure consistency with the constitution. This includes the executive's conduct of foreign relations. Yet the Constitutional Court has, in several judgments, recognised that the nature of foreign relations requires significantly more discretion for the executive than the exercise of public power in other contexts. The test established by the Court to determine whether that conduct in foreign relations is consistent with the Constitution is rationality. Under this general test, the executive should be given a wide margin of discretion and the courts should interfere with policy choices made by the executive only in exceptional cases. Moreover, the courts should avoid substituting their own policy preferences for those of the executive. With the exception of one case of the High Court, which was eventually overturned by the Supreme Court of Appeal, ${ }^{99}$ in the pre-Zuma era, the courts did not unnecessarily intervene unless there was a clear and unjustified breach of the constitution. ${ }^{100}$

In the Zuma era, while the courts have continued to pay lip-service the constitutional doctrine of deference, they have shrunk the discretion accorded to the executive to the extent that it is nothing but an empty shell. Under this new judicial oversight framework, it is the courts, based on the policy preferences of the judges, who determine what treaties South Africa may or may not enter into, whether to call for a vote or accept consensus in international forums, how and whether to vote where a vote is called for in such forums and whether to accord or not to accord immunities. While, given the Zuma

$9^{8}$ See in this regard Earthlife Africa v. Minister of Energy 2017 (5) SA 227, at para. 114 noting agreements requiring approval of parliament are those that 'generally engage or warrant the focussed attention or interest of Parliament'.

99 Von Abo v. the Government of the Republic of South Africa and Others [2008] ZAGPHC 226.

100 An example of a case where the Court did intervene is Mohamed and Another v. President of the Republic of South Africa 2001 (3) SA 893 (CC). 
administration's corruption-riddled tenure, very often the courts' policy preferences are understandable, it is a dangerous path when courts begin to assume the role of policy-maker, no matter how laudable the policy may be - after all, the road to hell is paved with good intentions.

It is still too early to tell whether the Zuma-era approach will continue in the Ramaphosa era, particularly since not a single foreign relations-related decision of the Ramaphosa administration is yet to be challenged. However, because the courts have, while constraining the discretion of the executive, maintained, at least as rhetoric, the Kaunda balance, underdoing the Zumaera jurisprudence should not be too difficult. 